\title{
PERFORMATIVE MORPHOLOGY IN ARCHITECTURE \\ Integrative Design Research by the Institute for Computational Design
}

\author{
A B S S T R A
}

Computation, in its most basic meaning, refers to the processing of information. In this way, both machinic processes operating in the binary realm of the digital, as well as material processes operating in the complex domain of the physical can be considered computational. While there is a strong bias towards the former in contemporary design, sporadic investigations of the later have also occurred in architecture. What is more rarely explored, though, is the territory where machine computation and material computation potentially overlap, where they not simply co-exist but intensely interact in the design process. Such an integrative approach to machine and material computation forms a central part of the research pursued at the Institute for Computational Design at the University of Stuttgart. This paper will introduce the related design research through the presentation of three research projects.

The first part of the paper focuses on the explanation of the theoretical framework of the Institute's approach to design computation, which finds its conceptual roots in the integrative processes of biological becoming rather than the striated processes of established technological production. It seeks to outline novel possibilities for a higher level of integration of form, information and performance in architecture through the possible synthesis of machine and material computation in morphogenetic design. The second part of the paper will provide specific examples of such a computational approach by introducing three related research areas. The possible integration of material behaviour as an active driver in computational design processes will be introduced through a first research project focusing on bending-active structures constructed from thin plywood lamellas. The second research project constitutes an example for the integration of materialization characteristics by encoding the possibilities and limits of robotic fabrication for modular wood shell structures in design computation. The third research project introduces the integration of material structure by embedding the complex reciprocities of form, material, structure and performance resulting from robotic carbon and glass fibre filament winding in a generative morphogenetic design process.

KEY WORDS 


\section{INTEGRATIVE DESIGN COMPUTATION}

Different from most current uses of computational design and digital fabrication in architecture, the research of the Institute for Computational Design is based on a synthesis of form, material, structure and performance in the process of integrative design computation. This approach finds its conceptual roots in the processes of becoming in nature ${ }^{1}$ : Natural morphogenesis, the process of individual growth and evolutionary development, derives the complex organisation, structure and shape of natural systems from the interaction of system intrinsic material capacities and external influences and forces. The resultant, astounding articulation, performative capacity and material resourcefulness, emerges through morphological differentiation, the summary process of each element's response and adaptation to its specific environment. ${ }^{2}$

In contrast to the reciprocities characteristic of the $r$ natural systems, the relation between information, formation and materialization in architecture is typically linear and, at least in regards to the genesis of form and its materialization, unidirectional and hierarchical. Whereas material plays an active role in the generation of biological form, in architecture it is most commonly conceived as a passive receptor of otherwise determined shape. Since the Renaissance, the rising separation between the processes of design and making, and the subsequent development of representational design techniques based on descriptive geometry has led to an increasing division between design methods and subsequent processes of production, fabrication and assembly. ${ }^{3}$ Thus far the advent of widespread and increasingly ubiquitous use of machine computation in architecture had seemingly very little effect on this condition. While the integrative character of computational design has been extensively utilized for the inclusion of programmatic, structural, environmental or economic information, material information is hardly ever considered, let alone employed, as a generative driver in design. Especially in recent years one could witness a widening conceptual gap between the generation of form in the realm of the virtual and its manifestation in the physical world. Emblematic for this schism is the strange coactive development, where the ability of digital design to generate ever more exotic shapes has been facilitated and accelerated by the ability of digital fabrication to produce them. ${ }^{4}$ It seems as if the age-long predominance of shape-oriented representational design techniques based on explicit geometry and their direct, conceptual extension in most contemporary CAD packages still preconditions contemporary design thinking. ${ }^{5}$ Even in otherwise progressive and behaviour-oriented design approaches materiality is still conceived as a passive property of shape and materialization understood 
as subordinate to the creation of form. ${ }^{6}$ Based on the understanding of form, material, structure, fabrication and assembly not as separate elements or processes, but rather as complex interrelations, our research focuses on a different approach to computational design and digital fabrication, one in which materialisation and computation is inherently and inseparably related. Algorithmic, computational design lends itself to such an integrative approach, as it allows encoding the characteristics and constraints of materialization in the physical world within the virtual processes of generative design. ${ }^{7}$

Considering the overlap between machine and material computation as a potential domain of architectural enquiry and technological innovation requires an interdisciplinary approach to design research. In the morphogenetic process developed at the Institute for Computational Design in collaboration with structural engineers, biomimetic engineers, material scientists and biologists, the relevant material properties together with the variability and constraints of digital fabrication processes can be encoded in the generative design processes. Through this, any specific form or structure derived remains fully coherent with the logics and limits of materialization. Furthermore, the computational process of morphogenetic development is informed through constant feedback with digital simulation, which allows responding to the heterogeneity of external forces, environmental influences and functional requirements. In this approach the architect utilizes computation for exploring the space of design possibilities defined by the logics and constraints of materialization, which opens up the possibility for a novel coherency of form, material, structure and function: a performative, morphological differentiation ready to be built, or in other words, an uncomplicated complexity.

As examples for this integrative approach to design computation three research projects - the ICD/ITKE Research Pavilion 2010, 2011 and 2012 - will be briefly explained in the following paragraphs. They are all collaborative undertakings of the Institute for Computational Design and the Institute of Building Structures and Structural Design at the University of Stuttgart with additional project partners from the German Biomimetics Competence Network.

\section{INTEGRATING MATERIAL BEHAVIOUR}

Material computes. Any material construct can be considered as resulting from a system of internal and external influences and constraints. However, in architecture, digital design processes are rarely able to reflect these intricate 
relations. Whereas in the physical world material form is always inseparably connected to external forces and influences, in the virtual processes of computational design form and force are usually treated as separate entities, as they are divided into processes of geometric form generation and subsequent simulation based on specific material properties. The ICD/ITKE Research Pavilion 2010 - a collaborative research project by the Institute for Computational Design (ICD) and the Institute of Building Structures and Structural Design (ITKE) - demonstrates an alternative approach to computational design: here, the computational generation of form is directly driven and informed by material behaviour. The result is a bending-active structure made entirely of extremely thin, elastically-bent plywood strips (Figure 01, Figure 02).

The structure of the pavilion is entirely based on the elastic bending behaviour of birch plywood strips. The strips are robotically manufactured as planar elements, and subsequently connected so that elastically bent and tensioned regions alternate along their length. The force that is locally stored in each bent region of the strip, and maintained by the corresponding tensioned region of the neighbouring strip, greatly increases the structural capacity of the system. In order to prevent local points of concentrated bending moments, the locations of the connection points between strips needs to change along the structure, resulting in 80 different strip patterns constructed from more than 500 geometrically unique parts. The combination of both the stored energy resulting from the elastic bending during the construction process and the morphological differentiation of the joint locations enables a very lightweight system. The entire structure, with a diameter of more than twelve meters, can be constructed using only 6.5 millimetre thin birch plywood sheets (Figure 03).

The computational design model is based on embedding the relevant material behavioural features in parametric principles. These parametric dependencies were defined through a large number of physical experiments focusing on the measurement of deflections of elastically bent thin plywood strips. Based on 6400 lines of code one integral computational process derives all relevant geometric information and directly outputs the data required for both the structural analysis model and the manufacturing with a 6-axis industrial robot.

The structural analysis model is based on a FEM simulation. In order to simulate the intricate equilibrium of locally stored energy resulting from the bending of each element, the model needs to begin with the planar distribution of the 80 strips, followed by simulating the elastic bending and subsequent 


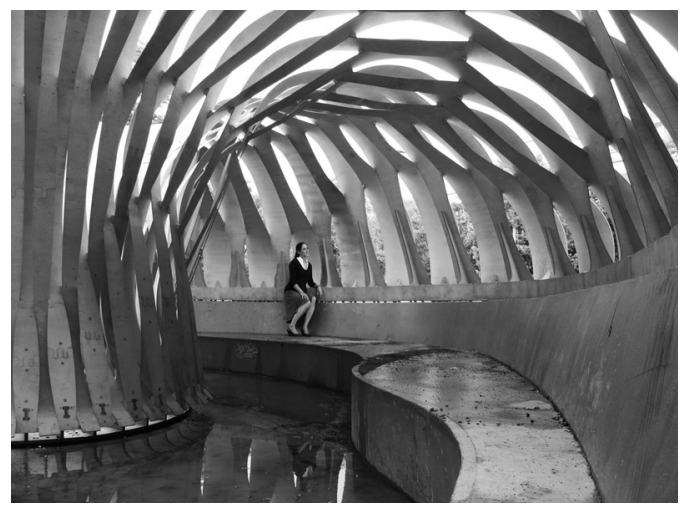

Figure 01 . Interior view, ICD/ITKE Research Pavilion 2010, Institute for Computational Design (Prof. Achim Menges) and Institute of Building Structures and Structural Design (Prof. Jan Knippers), Stuttgart, 2010.

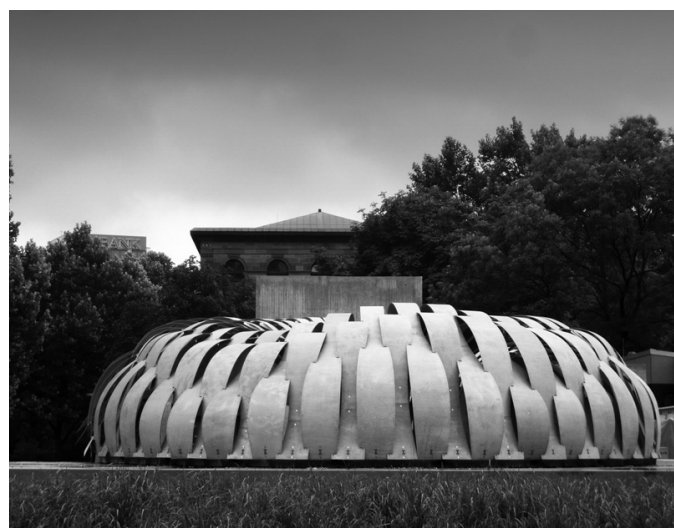

Figure 02. Exterior view, ICD/ITKE Research Pavilion 2010, Institute for Computational Design (Prof. Achim Menges) and Institute of Building Structures and Structural Design (Prof. Jan Knippers), Stuttgart, 2010.

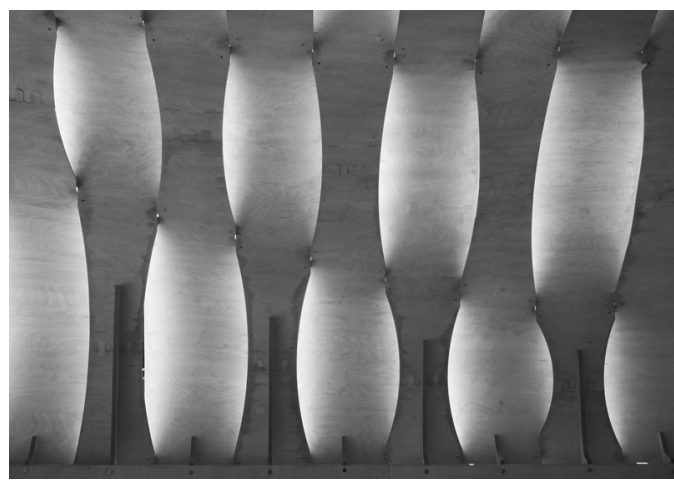

Figure 03. Close-up view, ICD/ITKE Research Pavilion 2010, Institute for Computational Design (Prof. Achim Menges) and Institute of Building Structures and Structural Design (Prof. Jan Knippers), Stuttgart, 2010.

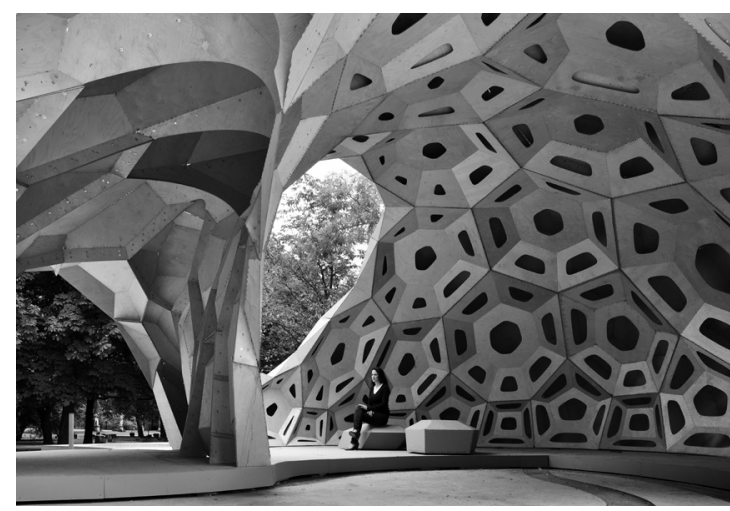

Figure 04. Interior view, ICD/ITKE Research Pavilion 2011, Institute for Computational Design (Prof. Achim Menges) and Institute of Building Structures and Structural Design (Prof. Jan Knippers), Stuttgart, 2011

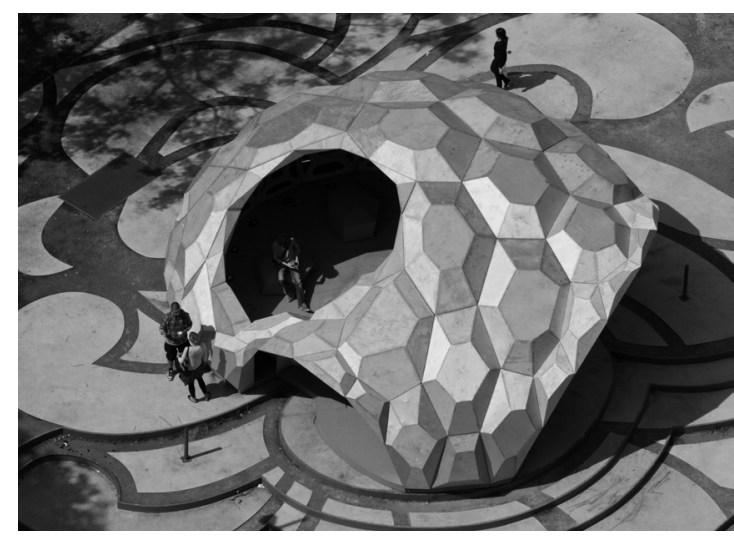

Figure 05. Exterior view, ICD/ITKE Research Pavilion 2011, Institute for Computational Design (Prof. Achim Menges) and Institute of Building Structures and Structural Design (Prof. Jan Knippers), Stuttgart, 2011.

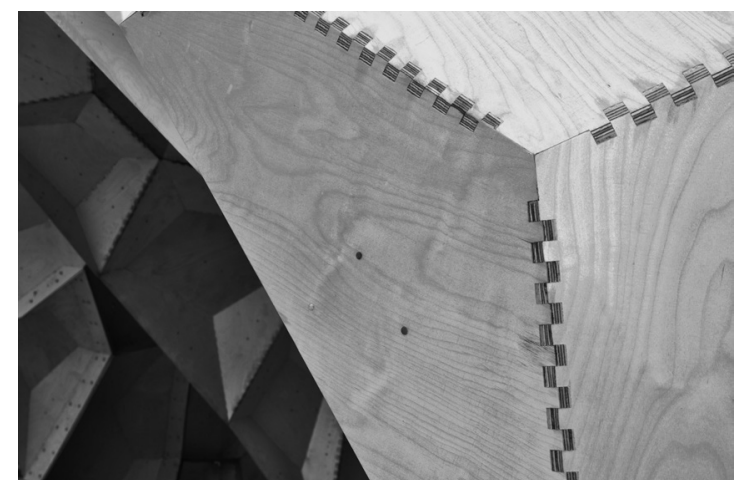

Figure 06. Close-up view, ICD/ITKE Research Pavilion 2011, Institute for Computational Design (Prof. Achim Menges) and Institute of Building Structures and Structural Design (Prof. Jan Knippers), Stuttgart, 2011. 
coupling of the strips. The detailed structural calculations, which are based on a specifically modelled mesh topology that reflects the unique characteristics of the built prototype, also allows for understanding the internal stresses that occur due to the bending of the material in relation to external forces such as wind and snow loads, a very distinct aspect of calculating lightweight structures.

Comparing the generative computational design process with the FEM simulation and the exact measurement of the geometry that the material computed on site demonstrates that the suggested integration of material behaviour in design computation is no longer an idealized goal but a feasible proposition. Thus, the project demonstrates how focusing the computational design process on material behaviour rather than geometric shape allows for unfolding performative capacity and material resourcefulness while at the same time expanding the design space towards hitherto unexplored architectural possibilities. Here, material is no longer a passive receptor of shape but an active generator of design.

\section{INTEGRATING MATERIALISATION CHARACTERISTICS}

There is no question that numerically controlled processes have already had a major effect on architectural production. But most often the use of digital fabrication is really of a facilitative rather than generative character. In contrast, the research presented here aims at overcoming a hierarchical conception of design computation and materialisation. The ICD/ITKE Research Pavilion 2011 demonstrates how systematically capturing the specific affordances and constraints inherent to a digital fabrication environment can become the point of departure for architectural inquiry and systematic design research.

The project-again a collaborative undertaking of the Institute for Computational Design (ICD) and the Institute of Building Structures and Structural Design (ITKE) as well as other partners of the Biomimetic Competence Network began with an investigation how digital production processes allow for an extension of traditional wood jointing techniques. The developed construction system is derived from two technological innovations: a special tool that was custom made by one of the projects industrial partners, which allows for simultaneously cutting with the tip and the edge of the tool, and the use of our industrial robot. These technological advances enable the development of robotically fabricated finger joints that enable the connection of wood plates at various different angles and even with different thicknesses, resulting in 
complex plate structures which still maintain the traditional finger joints' advantage of not requiring any additional mechanical fasteners.

Based on the specific robot set-up, the three critical morphological parameters of the finger - wood plates were identified and by employing a set-up specific robot fabrication simulation, the $\mathrm{min} / \mathrm{max}$ range for these morphological parameters was established and mapped into a so called "machinic morphospace". Within the theoretical morphospace of all geometrically possible plate morphologies, this machinic morphospace emerges that only includes the actually fabricable plate morphologies. Mapping the affordances and constraints of materialization into a design space in this way opens up the possibility to employ biomimetic design strategies to explore particularly promising regions of the machinic morphospace, which allow for unfolding performative capacity from morphological differentiation rather than surplus material. Thus, the project explores the architectural transfer of biological principles of the sea urchin's plate skeleton morphology by means of novel computer-based design and simulation methods, along with computercontrolled manufacturing methods for its building implementation. A particular innovation consists in the possibility of effectively extending the recognized bionic principles and related performance to a range of different geometries through computational processes, which is demonstrated by the fact that the complex morphology of the pavilion could be built exclusively with extremely thin sheets of plywood (Figure 04, Figure 05).

The project aims at integrating the performative capacity of biological structures into architectural design and at testing the resulting spatial and structural material-systems in full scale. The focus was set on the development of a modular system which allows a high degree of adaptability and performance due to the geometric differentiation of its plate components and robotically fabricated finger joints. During the analysis of different biological structures, the plate skeleton morphology of the sand dollar, a sub-species of the sea urchin (Echinoidea), became of particular interest and subsequently provided the basic principles of the bionic structure that was realized. The skeletal shell of the sand dollar is a modular system of polygonal plates, which are linked together at the edges by finger-like calcite protrusions. High load bearing capacity is achieved by the particular geometric arrangement of the plates and their joining system. Therefore, the sand dollar serves as a most fitting model for shells made of prefabricated elements. Similarly, the traditional fingerjoints typically used in carpentry as connection elements, can be seen as the technical equivalent of the sand dollar's calcite protrusions (Figure 06). 


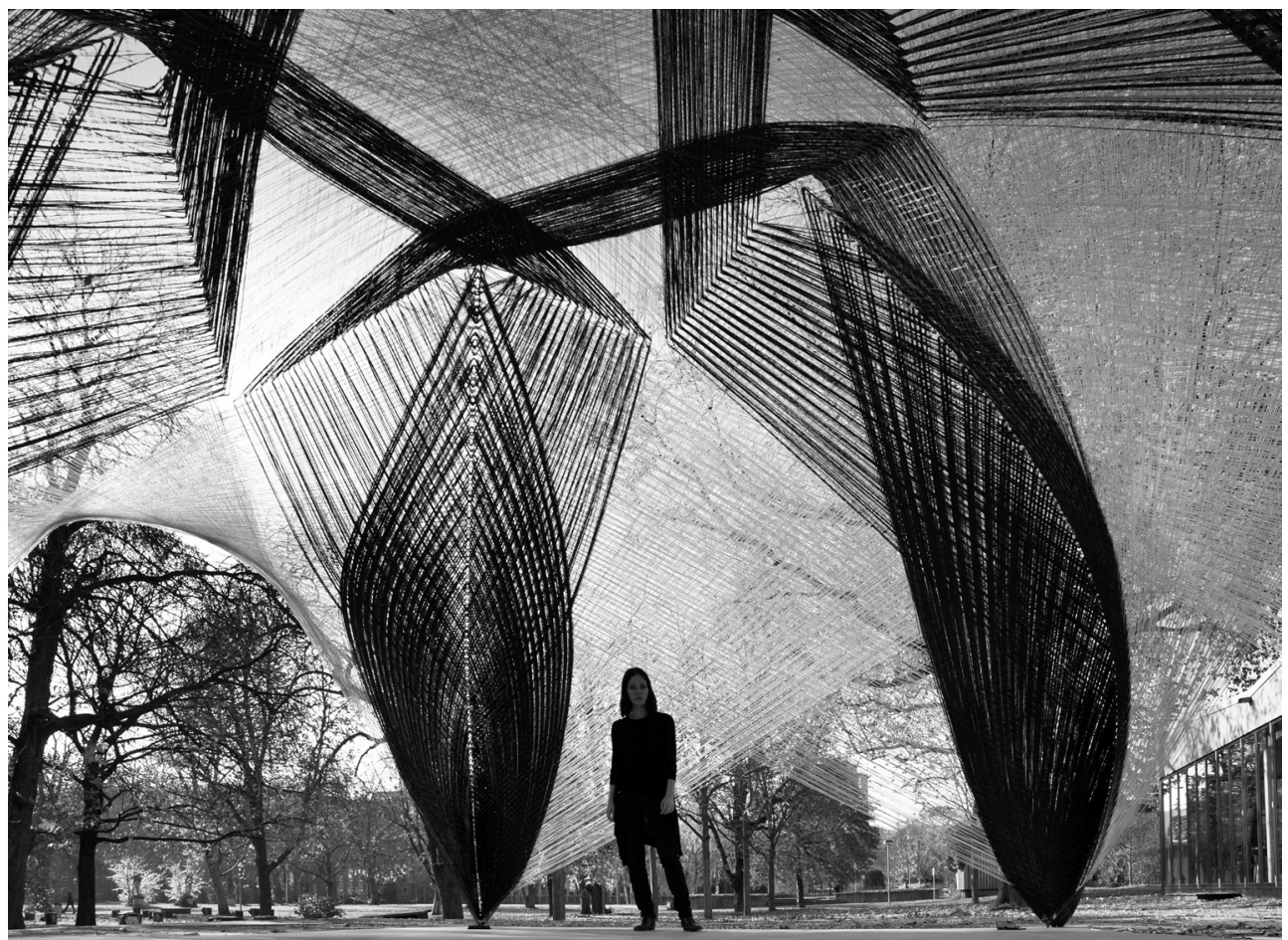

Figure 09. Interior view, ICD/ITKE ICD/ITKE Research Pavilion 2012, Institute for Computational Design (Prof. Achim Menges) and Institute of Building Structures and Structural Design (Prof. Jan Knippers), Stuttgart, 2012.

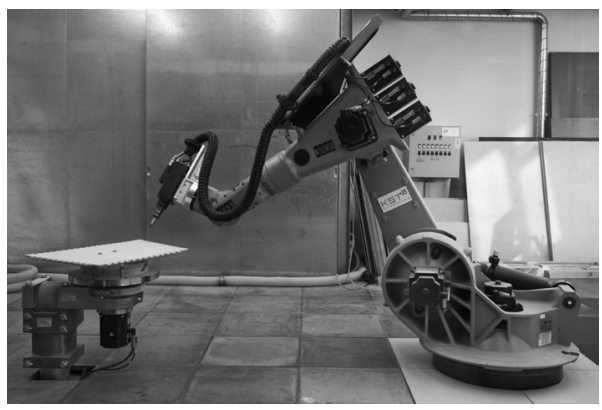

Figure 07 . Robotic manufacturing process, ICD/ITKE Research Pavilion 2011, Institute for Computational Design (Prof. Achim Menges) and Institute of Building Structures and Structural Design (Prof. Jan Knippers), Stuttgart, 2011.

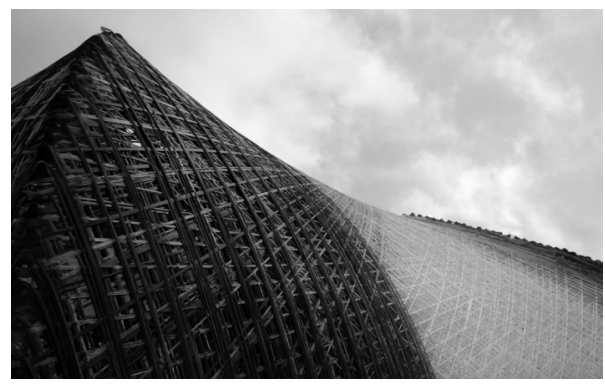

Figure 10. Close-up view, ICD/ITKE Research Pavilion 2012, Institute for Computational Design (Prof. Achim Menges) and Institute of Building Structures and Structural Design (Prof. Jan Knippers), Stuttgart, 2012.

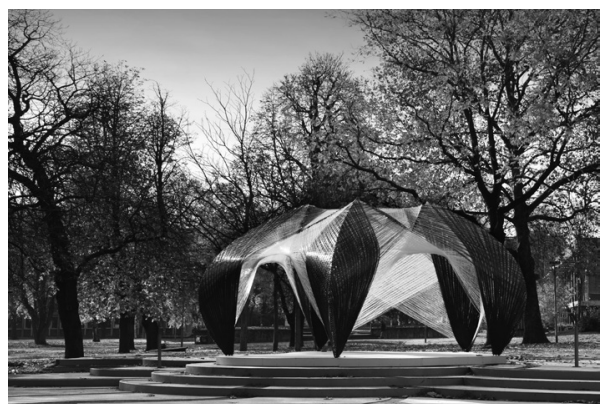

Figure 08. Exterior view, ICD/ITKE Research Pavilion 2012, Institute for Computational Design (Prof. Achim Menges) and Institute of Building Structures and Structural Design (Prof. Jan Knippers), Stuttgart, 2012.

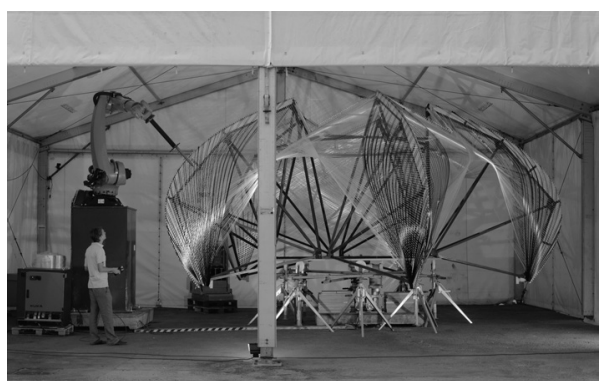

Figure 11. Robotic filament winding process, ICD/ ITKE Research Pavilion 2012, Institute for Computational Design (Prof. Achim Menges) and Institute of Building Structures and Structural Design (Prof. Jan Knippers), Stuttgart, 2012. 
Following the analysis of the sand dollar, the morphology of its plate structure was integrated in the design of a pavilion. Three plate edges always meet together at just one point, a principle which enables the transmission of normal and shear forces but no bending moments between the joints, thus resulting in a bending bearing but yet deformable structure. Unlike traditional lightweight construction, which can only be applied to load optimized shapes, this new design principle can be applied to a wide range of custom geometry.

A requirement for the design, development and realization of the complex morphology of the pavilion is a closed, digital information loop between the project's model, finite element simulations and computer numeric machine control. Form finding and structural design are closely interlinked. An optimized data exchange scheme made it possible to repeatedly read the complex geometry into a finite element program to analyse and modify the critical points of the model. In parallel, the glued and bolted joints were tested experimentally and the results included in the structural calculations.

The plates and finger joints of each cell were produced with the university's robotic fabrication system. Employing custom programmed routines the computational model provided the basis for the automatic generation of the machine code (NC-Code) for the control of an industrial seven-axis robot. This enabled the economical production of more than 850 geometrically different components, as well as more than 100,000 finger joints freely arranged in space. Following the robotic production (Figure 07), the plywood panels were joined together to form prefabricated building elements that were subsequently assembled on site.

As the structural performance here results from each elements specific morphological response, the entire pavilion with a diameter of more than 12 meters could be built using only extremely thin plates. In fact, all the plates, without any exception, have only a thickness of $6.5 \mathrm{~mm}$ resulting in a very lightweight and materially efficient structure that manages to enclose $200 \mathrm{~m}^{3}$ of space with only $2 \mathrm{~m}^{3}$ of wood. The project shows how integrating the characteristics of materialisation in a morphogenetic computational process enables the designer to offsets the conventional economies of construction: here a substantial intellectual investment in the design process results in a surprisingly simple system that still yields novel architectural possibilities while at the same time offering a high level of material efficiency and performative capacity. 


\section{INTEGRATING MATERIAL STRUCTURE}

The morphology of the sand dollar, as presented in the previous project, is quite an exceptional natural system in the sense that it follows relatively common principles of building construction based on assembling a larger structure from modules consisting of discreet elements. In contrast to this, most biological systems are based on a profoundly different logic, in which a clear distinction between material and structure is not possible: here materiality is constructed as an integrative material structure of continuous elements organized across multiple scales of hierarchy. Thus, in contrast to the previous project that constituted a shell built up from differentiated yet discreet modular elements, the next project aimed at a fundamentally different approach of developing an entirely continuous shell, in which the material structure itself is constructed and differentiated through robotic fabrication.

The interdisciplinary ICD/ITKE Research Pavilion 2012 project - conducted by the Institute for Computational Design (ICD) and the Institute of Building Structures and Structural Design (ITKE) in collaboration with biologists of the University of Tübingen - investigates the integration of material and structure in design computation through the possible interrelation of biomimetic design strategies and novel processes of robotic production. The research focused on the material and morphological principles of arthropods' exoskeletons as a source of exploration for a new composite construction paradigm in architecture.

At the core of the project is the development of an innovative robotic fabrication process within the context of the building industry based on filament winding of carbon and glass fibres and the related computational design tools and simulation methods. A key aspect of the project was to transfer the fibrous morphology of the biological role model to fibre-reinforced composite materials, the anisotropy of which was integrated from the start into the computer-based design and simulation processes, thus leading to new tectonic possibilities in architecture. The integration of the form generation methods, the computational simulations and robotic manufacturing, specifically allowed the development of a high performance structure: the pavilion requires only a shell thickness of four millimetres of composite laminate while spanning eight metres (Figure 08, Figure 09).

Following a "bottom-up" approach, a wide range of different subtypes of invertebrates were initially investigated in regards to the material anisotropy 
and functional morphology of arthropods. The observed biological principles were analysed and abstracted in order to be subsequently transferred into viable design principles for architectural applications. The exoskeleton of the lobster (Homarus americanus) was analysed in greater detail for its local material differentiation, which finally served as the biological role model of the project.

The lobster's exoskeleton (the cuticle) consists of a soft part, the endocuticle, and a relatively hard layer, the exocuticle. The cuticle is a secretion product in which chitin fibrils are embedded in a protein matrix. The specific differentiation of the position and orientation of the fibres and related material properties respond to specific local requirements. The chitin fibres are incorporated in the matrix by forming individual unidirectional layers. In the areas where a non-directional load transfer is required, such individual layers are laminated together in a spiral (helicoidal) arrangement. The resulting isotropic fibre structure allows a uniform load distribution in every direction. On the other hand, areas which are subject to directional stress distributions exhibit a unidirectional layer structure, displaying an anisotropic fibre assembly which is optimized for a directed load transfer. Due to this local material differentiation (Figure 10), the shell creates a highly adapted and efficient structure. The abstracted morphological principles of locally adapted fibre orientation constitute the basis for the computational form generation, material design and manufacturing process of the pavilion.

In collaboration with the biologists, the fibre orientation, fibre arrangement and associated layer thickness and stiffness gradients in the exoskeleton of the lobster were carefully investigated. The high efficiency and functional variation of the cuticle is due to a specific combination of exoskeletal form, fibre orientation and matrix. These principles were applied to the design of a robotically fabricated shell structure based on a fibre composite system in which the resin-saturated glass and carbon fibres were continuously laid by a robot, resulting in a compounded structure with custom fibre orientation.

In existing fibre placement techniques, e.g. in the aero-space industry or advanced sail production, the fibres are typically laid on a separately manufactured positive mould. Since the construction of a complete positive formwork is fairly unsuitable for the building industry, the project aimed at reducing the positive form to a minimum. As a consequence, the fibres were laid on a temporary lightweight, linear steel frame with defined anchor points between which the fibres were tensioned. From the straight segments of the pre-stressed fibres, surfaces emerge that result in the characteristic double 
curved shape of the pavilion. In this way the hyperbolic paraboloid surfaces resulting from the first sequence of glass fibre winding serve as an integral mould for the subsequent carbon and glass fibre layers with their specific structural purposes and load bearing properties. In other words, the pavilion itself establishes the positive formwork as part of the robotic fabrication sequence. Moreover, during the fabrication process it was possible to place the fibres so that their orientation is optimally aligned with the force flow in the skin of the pavilion. Fibre optic sensors, which continuously monitor the stress and strain variations, were also integrated in the structure. The project's concurrent consideration of shell geometry, fibre arrangement and fabrication process leads to a novel synthesis of form, material, structure and performance.

A prerequisite for the design, development and realization of the project was a closed, digital information chain linking the project's model, finite element simulations, material testing and robot control. Form finding, material and structural design were directly integrated in the design process, whereby the complex interaction of form, material, structure and fabrication technology could be used as an integral aspect of the biomimetic design methodology. The direct coupling of geometry and finite element simulations into computational models allowed for the generation and comparative analysis of numerous variations. In parallel, the mechanical properties of the fibre composites determined by material testing were included in the process of form generation and material optimization. The optimization of the fibre and layer arrangement through a gradient-based method, allowed for the development of a highly efficient structure with minimal use of material.

The robotic fabrication of the research pavilion was performed on-site in a purpose-built, weather-proof manufacturing environment by a 6 -axis robot coupled with an external seventh axis. Placed on a $2 \mathrm{~m}$ high pedestal and reaching an overall working span and height of $4 \mathrm{~m}$, the robot placed the fibres on the temporary steel frame, which was actuated in a circular movement by the robotically controlled turntable (Figure 11). As part of the fabrication process the fibres were saturated with resin while running through a resin bath directly prior to the robotic placement. This specific setup made it possible to achieve a structure of approximately $8.0 \mathrm{~m}$ in diameter and $3.5 \mathrm{~m}$ height by continuously winding more than 30 kilometres of fibre rovings. The parametric definition of the winding motion paths in relation to the digital geometry model, the robotic motion planning including mathematical coupling with the external axis, as well as the generation of robot control code itself could be implemented in a custom-developed design and manufacturing integrated 
environment. After completion of the robotic filament winding process and the subsequent tempering of the fibre-resin composite, the temporary steel frame could be disassembled and removed. The remaining, extremely thin shell of just $4 \mathrm{~mm}$ thickness constitutes an automatically fabricated, but locally differentiated structure.

The concurrent integration of the biomimetic principles of the lobster's cuticle and the logics of the newly developed robotic carbon and glass fibre filament winding within the computational design process, enable a high level of structural performance and novel tectonic opportunities for architecture. Despite its considerable size and span, the semi-transparent skin of the pavilion weighs less than $320 \mathrm{~kg}$ and reveals the system's structural logic through the spatial arrangement of the carbon and glass fibres. The synthesis of novel modes of computational and material design, digital simulation and robotic fabrication allows both the exploration of a new repertoire of architectural possibilities and the development of extremely lightweight and materially efficient structures.

\footnotetext{
NOTES

N.B.

PROJECT

ICD/ITKE Research Pavilion 2010: Institute for Computational Design - Prof. Achim Menges,

CREDITS Institute of Building Structures and Structural Design - Prof. Jan Knippers.

Concept and Realisation: Andreas Eisenhardt, Manuel Vollrath, Kristine Waechter with Thomas Irowetz, Oliver David Krieg, Admir Mahmutović, Peter Meschendoerfer, Leopold Moehler, Michael Pelzer, Konrad Zerbe. Scientific Development: Moritz Fleischmann (Project Management), Christopher Robeller (Detailing/Construction Management), Karola Dierichs (Documentation), Simon Schleicher (Project Management), Julian Lienhard (Structural Engineering), Diana D' Souza (Structural Engineering).

ICD/ITKE Research Pavilion 2011: Institute for Computational Design - Prof. Achim Menges, Institute of Building Structures and Structural Design - Prof. Jan Knippers.

Concept and System Development: Oliver David Krieg, Boyan Mihaylov. Detail Design, Fabrication and Construction: Peter Brachat, Benjamin Busch, Solmaz Fahimian, Christin Gegenheimer, Nicola Haberbosch, Elias Kästle, Oliver David Krieg, Yong Sung Kwon, Boyan Mihaylov, Hongmei Zhai. Scientific Development: Markus Gabler (Project Management), Riccardo La Magna (Structural Design), Steffen Reichert (Detail Design), Tobias Schwinn (Project Management), Frédéric Waimer (Structural Design). In collaboration with: Biomimetic Competence Network.
} 
ICD/ITKE Research Pavilion 2012: Institute for Computational Design - Prof. Achim Menges, Institute of Building Structures and Structural Design - Prof. Jan Knippers, Biomimetic Competence Network.

Concept Development: Jakob Weigele, Manuel Schloz. System Development and Realization: Sarah Haase, Markus Mittner, Josephine Ross, Manuel Schloz, Jonas Unger, Simone Vielhuber, Franziska Weidemann, Jakob Weigele, Natthida Wiwatwicha with the support of Michael Preisack, Michael Tondera. Scientific Development and Project Management: Riccardo La Magna (Structural Design), Steffen Reichert (Detail Design), Tobias Schwinn (Robotic Fabrication), Frédéric Waimer (Fibre Composite Technology \& Structural Design). In collaboration with: Biomimetic Competence Network, Department of Evolutionary Biology of Invertebrates, University of Tuebingen - Prof. Oliver Betz, Department of Palaeontology of Invertebrates, University of Tuebingen - Prof. James Nebelsick, ITV Denkendorf - Dr.Ing. Markus Milwich.

Achim Menges, "Biomimetic design processes in architecture: morphogenetic and evolutionary computational design," Bioinspiration and Biomimetics Vol. 7 No. 1. (2012).

Jan Knippers and Thomas Speck, "Design and construction principles in nature and architecture," Bioinspiration and Biomimetics, Vol. 7 No. 1. (2012).

Mario Carpo, The Alphabet and the Algorithm (Cambridge: MIT Press, 2011).

Achim Menges, "Form Generation and Materialization at the Transition from Computer-aided to Computational Design," Detail 04 (2010): 330-335.

Kostas Terzidis, Algorithmic Architecture (Oxford: Architectural Press, 2006).

Mark Burry, Scripting Cultures - Architectural Design and Programming (London: Wiley, 2011). Achim Menges,"Material Resourcefulness: Activating Material Information in Computational Design," Architectural Design, Vol. 82 No. 2 (2012):34-43. Carpo, Mario. The Alphabet and the Algorithm. Cambridge: MIT Press, 2011.

Knippers, Jan and Speck, Thomas. "Design and construction principles in nature and architecture." Bioinspiration and Biomimetics, Vol. 7 No. 1. (2012)

Menges, Achim. "Form Generation and Materialization at the Transition from Computer-aided to Computational Design." Detail No. 04 (2010): 330-335.

Menges, Achim."Biomimetic design processes in architecture: morphogenetic and evolutionary computational design." Bioinspiration and Biomimetics, Vol. 7 No. 1. (2012).

Menges, Achim. "Material Resourcefulness: Activating Material Information in Computational Design.” Architectural Design Vol. 82 No. 2 (2012): 34-43.

Terzidis, Kostas. Algorithmic Architecture. Oxford: Architectural Press, 2006. 


\section{PERFORMATIVNA MORFOLOGIJA U ARHITEKTURI \\ Istraživanje integrativnog projektovanja sprovedenog od strane Instituta za računarsko projektovanje}

\section{Achim Menges}

Računarstvo, u svom najosnovnijem značenju, odnosi se na obradu podataka. $\mathrm{Na}$ taj način, i mašinski procesi koji rade u binarnom carstvu digitalnog, kao što i materijalni procesi rade u kompleksnom domenu fizičkog, mogu se smatrati računarskim. Iako postoji jako predubeđenje prema prvo navedenom u savremenom projektovanju, došlo je do sporadičnih ispitivanja ovog drugog gore navedenog u arhitekturi. Ono što se ređe istražuje, međutim, je teritorija gde se mašinsko računarstvo i računarstvo materijala preklapaju, gde oni jednostavno samo ne koegzistiraju već intezivno sadejstvuju u procesu projektovanja. Takav integrativni pristup mašinskom i materijalnom računarstvu sačinjava centralni deo istraživanja koji se sprovodi u Institutu za računarsko projektovanje, Univerziteta u Štutgartu. Ovaj rad će predstaviti istraživanja projektovanja kroz tri istraživačka projekta.

Prvi deo rada se fokusira na objašnjavanje teoretskog okvira pristupa Insitituta za računarsko projektovanje, koji svoje konceptualne korene nalazi u integrativnim procesima biološkog postajanja pre nego u izbrazdanim procesima ustaljene tehnološke proizvodnje. On teži da okvirno prikaže nove mogućnosti za viši nivo integracije forme, informacije i performanse u arhitekturi kroz moguću sintezu mašinskog računarstva i računarstva materijala u morfogenetskom projektu. U drugom delu ovog rada daju se specifični primeri takvog računarskog prilaza predstavljanjem tri povezane oblasti istraživanja. Moguća integracija ponašanja materijala kao aktivnog upravljača u procesima računarskog projektovanja će biti predstavljena putem prvog istraživačkog projekta koji se fokusira na savitljive - aktivne konstrukcije konstruisane od lamela tanke iverice. Drugi istraživački projekat sačinjava primer integracije svojstava materijalizacje kodiranjem mogućnosti i ograničenja robotičke izrade za modularne drvene opnaste konstrukcije u računarskom projektovanju. U trećem istraživačkom projektu predstavljena je integracija materijalnih struktura utemeljavanjem reciprociteta forme, materijala, strukture i performanse koji proizilaze iz namotaja robotičkih niti ugljenikovih i staklenih vlakana u generativnom morfogenetskom procesu projektovanja. 